\title{
Kasvihuonetomaatti- ja kurkkulajikkeet
}

\author{
Juha Näkkilä
}

MTT Maa-ja elintarviketalouden tutkimuskeskus, puutarhatuotanto, Toivonlinnantie 518, 21500 Piikkiö juha.nakkila@mtt.fi

\section{Johdanto}

Närpiössä Martensin puutarhasäätiössä järjestettiin lajikekokeet, joissa vertailtiin tomaatti- ja kurkkulajikkeiden sadon määrää ja laatua sekä viljelijätuloa tunnettuihin verrannelajikkeisiin luonnon valossa. Laatutekijöistä päähuomio oli sadon ulkoisessa laadussa. Lajikekokeet järjestettiin puutarhasäätiön, Pohjanmaan kasvihuonetuotannon kehityshankkeen (VEXA) ja MTT:n yhteistyönä.

\section{Aineisto ja menetelmät}

Vertaillut tomaattilajikkeet olivat Rijk Zwaanin Aromata (verranne) ja numerolajike 7330, Bruinsma Seedsin lajike Axxion, Enza Zadenin lajike Splendor (entinen 24.31894) ja numerolajike 25.32221 sekä De Ruiter Seedsin lajike Dometica (ent. 72-225). Tomaatti istutettiin 29. tammikuuta vuonna 2003 pintaalaltaan 1850 neliömetrin lasikatteiseen huoneeseen. Taimet istutettiin paririviin ja istutustiheytenä oli 2,4 tainta neliömetrille. Kasvualustana käytettiin kivivillaa ja ylimääräinen kasteluliuos kierrätettiin hidashiekkasuodattimen kautta uudelleen kastelujärjestelmään. Kastelua ohjattiin aloituslaatikolla ja ajastimella. Satoa korjattiin 2. huhtikuuta ja 20. lokakuuta välisen ajan eli noin 29 viikkoa.

Otos ensimmäisen luokan tomaattisatoa luokiteltiin hedelmän halkaisijan suhteen kuusi kertaa. Kokoluokat olivat 47-56 mm, 57-66 mm, 67-81 ja vähintään $81 \mathrm{~mm}$. Touko- ja syyskuussa arvioi 10-11 hengen raati tomaatin maun miellyttävyyttä. Arviointiasteikko oli 1-9 (erittäin huono - erinomainen). Samalla mitattiin refraktometrilla hedelmistä puristetun mehun liukoisten sokerien ja happojen määrää. Raivauksen yhteydessä mitattiin varren pituus yhteensä 12 kasvista lajiketta kohti.

Testatut kurkkulajikkeet kevätviljelyyn olivat Rijk Zwaanin Armada (verranne) ja Ladner (ent. 24-70), Nunhemsin lajike Activa, Dahnfeldtin lajike Naomi ja De Ruiter Seedsin Tavares (ent. DRK 5826). Lajikkeiden Ladner, Naomi ja Tavares ilmoitetaan kestävän härmää. Kurkku istutettiin 12.-13. helmikuuta vuonna 2002 pinta-alaltaan 450 neliömetrin lasikatteiseen osastoon. Istutustiheys oli 1,6 tainta neliömetrille. Kasvualustana oli kivivilla. Kastelujärjestelmä oli avoin ja kastelua ohjattiin aloituslaatikolla ja ajastimella. Kasvit istutettiin yhteen kasvualustariviin, rivin taimet tuettiin vuorotellen 2,2 metrin korkeudella olevaan kahteen ylälankaan ja kasvit kasvatettiin sateenvarjoleikkausmenetelmällä. Kustakin kasvista kasvatettiin kaksi sivuversoa pääverson katkaisun jälkeen. Satoa kerättiin 13. maaliskuuta ja 11. kesäkuuta välisen ajan eli noin 13 viikkoa.

Otos ensimmäisen luokan kurkkusatoa luokiteltiin painon ja pituuden suhteen kahdeksaan otteeseen. Painoluokat olivat 250-349 g, 350-449 g, 450-599 g ja 600-700 g ja pituusluokat olivat 25-29 $\mathrm{cm}, 30-34 \mathrm{~cm}, 35-39 \mathrm{~cm}$ ja vähintään $40 \mathrm{~cm}$.

Lajikekokeet järjestettiin lohkoittain satunnaistettuina. Koelohkoja oli tomaatilla neljä ja kurkulla viisi. Sato kerättiin, lajiteltiin, laskettiin ja punnittiin kolme kertaa viikossa. Kauppakelpoiset hedelmät lajiteltiin muuten EU-säädösten mukaan, mutta extra luokan satoa ei lajiteltu erikseen, vaan se sisällytettiin ensimmäisen luokan satoon. Kauppakelpoisen sadon lisäksi lajiteltiin latvamätäiset, halkeilleet ja muut kauppakelvottomat tomaatit sekä muut kauppakelvottomat kurkut. Lajikkeesta saatava viljelijätulo laskettiin Osuuskunta Närpiön vihanneksen maksaman pakkaamattoman ja arvonlisäverottoman ensimmäisen ja toisen luokan hedelmän viljelijähinnan mukaan. Sadon painosta ja viljelijätulosta laskettiin varianssianalyysi. Lajikkeiden väliset erot testattiin Dunnettin testillä, joten keskiarvojen parittaiset vertailut rajattiin verrannelajikkeeseen. 


\section{Tulokset ja tulosten tarkastelu}

Tomaattilajikkeet olivat satoisuudeltaan ja viljelijätuloltaan varsin saman kaltaisia. Keskimäärin painavin sato ja suurin viljelijätulo saatiin Axxion-lajikkeesta, mutta mikään lajikkeista ei ollut kokonaissadon painon, ensimmäisen luokan sadon painon tai viljelijätulon suhteen merkitsevästi Aromata-verrannetta parempi (taulukko 1). Lajikkeiden kokonaissadosta oli 98-99 painoprosenttia ensimmäisen luokan satoa, joten sato oli varsin korkealaatuista ulkonäöltään. Aromata-verranteen suurin laatuongelma oli merkitsevästi muita lajikkeita suurempi toisen luokan sadon paino. Lajike tuottaa sadon alkuvaiheessa painavia ja epämuotoisia hedelmiä. Lajikkeilla Splendor, Dometica ja 7330 oli latvamätää merkitsevästi enemmän kuin verranteella.

Suuria, halkaisijaltaan vähintään 82 millimetrisiä tomaatteja ei ollut millään lajikkeella. Lajikkeiden Aromata, Axxion ja 25.32221 tomaatit olivat noin 100 gramman painoiset ja ne kuuluivat pääosin halkaisijaltaan 67-81 millimetrin kokoluokkaan. Dometica- ja 7330-lajikkeiden hedelmät painoivat noin 80 grammaa ja ne kuuluivat pääosin 57-66 millimetrin luokkaan. Splendor-lajike asettui hedelmän keskipainon suhteen edellisten ryhmien väliin ja hedelmät jakautuivat melko tasan molempiin edellä mainittuihin kokoluokkiin. Pieniä, halkaisijaltaan 47-56 millimetrin hedelmiä oli vain Aromata-, Dometica- ja 7330-lajikkeilla enintään yksi prosentti hedelmien lukumäärästä.

Tomaattien aistinvaraisessa arvioinnissa lajikkeet Aromata, Splendor, Dometica ja 7330 saivat molemmilla kerroilla raadilta yleisarvosanan hyvä. Axxion-lajike arvioitiin molemmilla kerroilla tyydyttäväksi ja numerolajike 25.32221 ensin keskinkertaiseksi ja sitten tyydyttäväksi. Lajikkeiden Axxion ja 25.32221 hedelmien mehussa oli keskimäärin alimmat liukoisten sokerien ja happojen pitoisuudet.

Aromata-, Axxion- ja Splendor-lajikkeilla oli varren pituus raivattaessa noin 7 metriä, mutta lajikkeilla Dometica, 25.32221 ja 7330 varret olivat vähintään 7,5 metrisiä.

Aromata-verranteella oli tässä kokeessa vain kaksi noin 100 grammaa painavia hedelmiä tuottavaa haastajaa; lajikkeet Axxion ja 25.32221. Ne olivat yhtä satoisia kuin Aromata-lajike ja niiden ensimmäisen luokan osuus kokonaissadosta oli hieman parempi kuin Aromata-lajikkeella. Axxion- ja 25.32221lajikkeiden heikkoudeksi osoittautui hedelmän vaatimaton maku. Makua voi yrittää parantaa esimerkiksi poimimalla hedelmät tavanomaista kypsempinä, mutta tämä voi heikentää hedelmien käsittelykestävyyttä. Numerolajikkeen 25.32221 Aromata-lajiketta suurempi pituuskasvu edellyttää korkeampaa kasvihuonetta tai enemmän alaslaskutyötä viljelyn aikana. Kevyempiä hedelmiä tuottavat lajikkeet Splendor, Dometica ja 7330 olivat Aromata-lajikkeen veroisia satoisuuden, sadon ulkoisen laadun ja hedelmän maun suhteen. Nämä lajikkeet tarvitsevat verranteesta poikkeavan kastelu- ja lannoituskäytännön, jolla latvamätää voi vähentää. Lajikkeet Dometica ja 7330 olivat Aromata-lajiketta pitempikasvuisia ja todennäköisesti siis työläämpiä viljellä. Aromata-lajikkeen toisen luokan sadon määrää voi pienentää poistamalla suuret, epämuotoiset hedelmät ajoissa.

Vain Activa-kurkkulajike oli merkitsevästi satoisampi ja viljelijätuloltaan tuottoisampi kuin Armadaverranne (taulukko 2). Ladner-lajike oli yhtä satoisa ja tuottoisa kuin verranne. Lajikkeilla Naomi ja Tavares oli merkitsevästi pienempi ensimmäisen luokan sadon paino tai viljelijätulo verrattuna Armadaverranteeseen. Kurkkulajikkeilla oli ensimmäisen luokan satoa 91-94 prosenttia koko sadon painosta ja Armada-verranteella ensimmäisen luokan osuus oli korkein.

Kurkkujen kokoluokittelussa ei ollut lainkaan 600-700 grammaa painavia kurkkuja tai vähintään 40 senttimetriä pitkiä kurkkuja. Nämä kokoluokat eivät yleensä ole kuluttajien suosiossa. Ladner-lajiketta lukuunottamatta yli 90 prosenttia lajikkeiden kurkkujen lukumäärästä oli alle 450 gramman hedelmiä. Tavares-lajikkeella kurkkujen paino vaihteli vähiten, 76 prosenttia kurkuista sijoittui keskipainoisten, 350449 gramman luokkaan. Activa- ja Naomi-lajikkeilla oli Armada-verrannetta enemmän kevyitä, 250-349 grammaa painavia kurkkuja ja Ladner-lajikkeella verrannetta enemmän painavia, 450-599 grammaa painavia kurkkuja. Kevyiden ja painavien hedelmien osuutta voi muuttaa, kun satoa korjataan useammin. Kurkun pituus ei vaihdellut paljoa samanikäisessä kasvustossa, vaan saman lajikkeen kurkut mahtuivat yleensä kahteen peräkkäiseen pituusluokkaan. Armada-verranteella kurkkujen pituus vaihteli vähiten, 85 prosenttia kurkkujen lukumäärästä oli keskipitkiä, pituudeltaan 30-34 senttimetriä. Tavares- ja Ladnerlajikkeilla oli verrannetta enemmän pitkiä, 35-39 senttimetrin kurkkuja, kun satoa korjattiin sivuversoista. 


\section{Johtopäätökset}

Tomaatin lajikekokeessa ei löytynyt selkeästi Aromata-verrannetta parempaa lajiketta. Kaikki testatut lajikkeet Axxion, Dometica, Splendor, 25.32221 ja 7330 olivat yhtä satoisia ja tuottivat yhtä suuren viljelijätulon kuin Aromata-verranne. Ulkonäöltään laadukkaiden lajikkeiden Axxion ja 25.32221 hyvää tulosta himmentää hedelmien vaatimaton maku. Jos tavoitteena on tuottaa keskimäärin 100 gramman tomaatteja, on Aromata-lajike varmin vaihtoehto tuottaa hyvän makuisia hedelmiä. Jos tavoitteena ovat kevyemmät, keskimäärin 80-90 grammaa painavat hedelmät, hyviä vaihtoehtoja ovat lajikkeet Splendor, Dometica ja 7330 .

Activa-kurkkulajike oli satoisampi ja tuotti suuremman viljelijätulon kuin Armada-verrannelajike. Härmää kestäviksi ilmoitetuista lajikkeista vain Ladner-lajike pystyi tuottamaan yhtä suuren sadon ja viljelijätulon kuin verranne. Naomi- ja Tavares-lajikkeet tuottivat Armada-verrannetta vähemmän viljelijätuloa tai ensimmäisen luokan satoa.

Taulukko 1. Lajikkeen vaikutus tomaattisadon määrään, viljelijätuloon ja ensimmäisen luokan hedelmän keskipainoon 2.4.- 20.10.2003

\begin{tabular}{lllllr}
\hline Lajike & $\begin{array}{l}\text { Kokonais- } \\
\text { sato } \\
\mathrm{kg} / \mathrm{m}^{2}\end{array}$ & $\begin{array}{l}\text { 1. luokan } \\
\text { sato } \\
\mathrm{kg} / \mathrm{m}^{2}\end{array}$ & $\begin{array}{l}2 . \text { luokan } \\
\text { sato } \\
\mathrm{kg} / \mathrm{m}^{2}\end{array}$ & $\begin{array}{l}\text { Viljelijä- } \\
\text { tulo } \\
\text { euro } / \mathrm{m}^{2}\end{array}$ & $\begin{array}{l}\text { 1. luokan } \\
\text { hedelmän } \\
\text { keskipaino } \\
\mathrm{g} / \mathrm{kpl}\end{array}$ \\
\hline Aromata (verranne) & 41,23 & 40,43 & 0,65 & 38,49 & 98 \\
Axxion & 42,42 & 42,16 & $0,15^{* * *}$ & 39,30 & 100 \\
25.32221 & 42,40 & 41,95 & $0,30^{* * *}$ & 39,18 & 97 \\
Splendor & 40,30 & 39,33 & $0,48^{* *}$ & 37,62 & 89 \\
Dometica & 41,44 & 40,77 & $0,25^{* * *}$ & 38,88 & 78 \\
7330 & 39,74 & 38,92 & $0,31^{* * *}$ & 36,87 & 84 \\
\hline
\end{tabular}

Taulukko 2. Lajikkeen vaikutus kurkkusadon määrään, viljelijätuloon ja ensimmäisen luokan hedelmän keskipainoon 13.3.- 11.6.2002

\begin{tabular}{llllll}
\hline Lajike & $\begin{array}{l}\text { Kokonais- } \\
\text { sato } \\
\mathrm{kg} / \mathrm{m}^{2}\end{array}$ & $\begin{array}{l}\text { 1. luokan } \\
\text { sato } \\
\mathrm{kg} / \mathrm{m}^{2}\end{array}$ & $\begin{array}{l}2 . \text { luokan } \\
\text { sato } \\
\mathrm{kg} / \mathrm{m}^{2}\end{array}$ & $\begin{array}{l}\text { Viljelijä- } \\
\text { tulo } \\
\text { euro/m }\end{array}$ & $\begin{array}{l}\text { 1. luokan } \\
\text { hedelmän } \\
\text { keskipaino } \\
\mathrm{g} / \mathrm{kpl}\end{array}$ \\
\hline Armada (verranne) & 18,57 & 17,51 & 1,06 & 13,40 & 363 \\
Activa & $20,41^{*}$ & $19,05^{*}$ & 1,36 & $14,70^{*}$ & 344 \\
Naomi & 17,55 & 16,38 & 1,17 & $12,14^{*}$ & 345 \\
Tavares & $16,96^{\circ}$ & $15,48^{*}$ & 1,47 & 12,65 & 365 \\
Ladner & 18,24 & 16,78 & 1,46 & 12,46 & 367 \\
\hline
\end{tabular}

